\title{
STAGING NANCY CUNARD: THE QUESTION OF PERSONA IN DRAMATIZING HER LIFE AND WORK
}

\author{
SASHA COLBY
}

\begin{abstract}
Nancy Cunard presents us with one of modernism's most concentrated examples of the role of persona in shaping the reception of a literary figure. A writer, publisher, and activist, Cunard was firmly entrenched in the working world, an attachment that she makes clear in her varied autobiographical writings. By contrast, the tabloid press, other modernists, and critics have deployed various versions of Cunard-a series of personas marked by their variety (racist vs. race reformer; dilettante vs. pioneering intellectual); the intensity of the debate as to which one constitutes the "real" Nancy Cunard; and, frequently, the marked exclusion of many of Cunard's working activities. In this process-based account, the author considers the range and scope of the personas that have circulated around Cunard, Cunard's establishment of a working counter-persona in her autobiographical writing, and the processes of working with these competing iterations in her play about Cunard's life and work, These Were the Hours.
\end{abstract}

\section{KEY WORDS}

Nancy Cunard, Research-creation, Persona, Press, Authorship, Work

\section{CRITICAL INTRODUCTION TO NANCY CUNARD}

Nancy Cunard (1896-1965) was a British writer, activist, and publisher. As this list suggests, Cunard was heavily invested in the realm of work. And yet, as the one-time heiress to the Cunard shipping fortune, a press icon in her early twenties, and later, a society scandal as a result of her involvement in race activism, the personas that circulated in her own time and those that continue to circulate are intriguingly detached from the realm of labour. Undoubtedly some of this had to do with Cunard's class position and the perception that she did not need to work; her family's money, though later threatened by a tumultuous relationship with her mother, made her a part of the leisure class, a distinction which on many counts undercut the perceived need-and, as a result the perceived value-of the work itself. Moreover, Cunard's involvement in race activism - both her strident engagements with black causes and more questionable performances of black aesthetics through her wardrobe and photographs by Man Ray and Barbara Ker-Seymer-were controversial and sensational in ways that occluded and have continued to occlude more mundane acts of writing, editing, and publishing. Throughout her life, Cunard was acutely conscious of this omission: images created for her through and by the press, and subsequently in thinly-veiled literary depictions and autobiographical accounts by her contemporaries, eclipsed the work that was central to her own sense of identity. The fact that Cunard's own memoirs are largely accounts of her workrunning The Hours Press in Paris and Normandy, editing the controversial 800-page Negro 
Anthology, and on-the-ground reporting during the Spanish Civil War for The Manchester Guardian-could well be read as a response to this perceived omission.

The result is that almost any critical work on Cunard creates an awareness of personas, both those that surround Cunard and can be variously counted as "party-girl," "eccentric bohemian," "race trouble-maker," and a variety of sexualized derivations, as well as Cunard's counter-persona, the careful, thoughtful, working woman who appears in her memoirs, These were the Hours: Memories of My Hours Press Réanville and Paris 1928-1931 (1969), GM: Memories of George Moore (1956), and Grand Man: Memories of Norman Douglas (1954). As Susan Stanford-Friedman writes, issues of persona have been key to critical assessments of Cunard's credibility and importance as "[i]t has been difficult for critics to sort out the serious writer and political organizer from the legends of her life fed by publicity and personality" (64). In working on a dramatization of Cunard's life and work, These Were the Hours, in my research-creation book, Staging Modernist Lives: H.D, Mina Loy, Nancy Cunard (currently under university press review), the question of persona as it attaches itself to Cunard has become particularly concentrated. As P. David Marshall and Kim Barbour note in the inaugural issue of this journal, the word "persona" is at once conceptually appropriate to the "strategic masks of identity" applied to complex expressions of personality and is etymologically connected to the masks of the Greek theatre (1-2). In staging Cunard, both are at play: the masks applied to Cunard and the strategic masks she adopted in response, and, in the course of writing the script, the processes of dramatic characterization emblematized by the theatrical mask. In this sense, the space between the theatrical and identity-based definitions of persona in many ways encapsulates the central tension in dramatizing Cunard, a schism which I will here use as pressure point for a process-based consideration of researching and writing These Were the Hours.

In analyzing Cunard's press-made personas, it is the arc of the characterization which is the most startling. As an attractive young woman from a prominent family, Cunard was a press darling, particularly when, at age twenty, she unexpectedly married Australian army officer, Sydney Fairbairn. As Lois Gordon notes in her biography of Cunard, at least twenty-seven items appeared about the engagement and still more about the marriage itself, with reports including commentary on "the brave deserving the fair" and Miss Cunard as "'an exquisite specimen of English girlhood' ... Her hobby in life will probably be dogs" (63). When the marriage to Fairbairn ended after only twenty months and Cunard moved to Paris and went on to publish Outlaws, Sublunary, and Parallax, influenced by both English and French avant-garde movements, the British press continued to focus on her clothes and speculate on when she might return to London. The clippings Cunard kept (in her voluminous scrapbooks, currently housed at the Harry Ransom Research Center in Austin, Texas), were for occasional reviews of her poetry, including an Evening Standard comment on the "dignified intellectual quality" of Outlaws. Press coverage of Cunard's early Paris years are largely studded with amused commentary on Cunard's bohemian proclivities. However, when the press became aware of Cunard's relationship with the black, American musician Henry Crowder, the tide turned significantly. It was a reporter who asked Nancy Cunard's mother if she had heard of her daughter's black "friend," "the Negro musician, Henry Crowder," to which Lady Cunard famously responded: "Do you mean to say my daughter actually knows a Negro?" (qtd. in Gordon 157). But this incident also marked the beginning of a press campaign deriding Cunard's character and her politics, and culminated in a series of articles in both British and American newspapers suggesting Cunard's 1932 visit to Harlem (to collect materials for Negro) was undertaken primarily in order to participate in sexual escapades, notably with actor and activist Paul Robeson.

The trajectory of Cunard's relationship with the press is indicative not only of the ways in which pressuring social limits can lead to tabloid creation of a negative public image, but also, in a larger sense, of the intricate relationship between modernism and celebrity. As Christine Geraghty suggests: "celebrity indicates someone whose fame rests overwhelmingly on 
what happens outside the sphere of their work and who is famous for having a lifestyle. The celebrity is thus constructed through gossip, press and television reports, magazine articles and public relations" (99). Constructed and understood as a celebrity, Cunard and her venture into highly politicized activities may not only have been perceived as transgressive from the point of view of race and class (which it definitively was), but also destabilizing to the nature of the celebrity for which she was known. As Franco Alberoni has argued:

A phenomenon like 'stardom' does not exist unless certain systems of action are institutionally considered as unimportant from a political point or view. In other words 'stars' exist in that measure to which their activities are not mainly evaluated according to the consequences which they involve for the collectivity. There is a social mechanism of separation which, put schematically, holds that the 'stars' do not occupy institutional positions of power. (109)

Certainly this is true in Cunard's case where the venture into the political sphere-and the politics of race in particular-considerably altered the nature of her coverage by the press. From the time Cunard married Fairbairn in 1916 to the trip to Harlem in 1932, the narrative had changed from "princess-gets-her-prince" to "charming-but-errant-heiress" to "sex-crazedpolitical-trouble-maker."

Contributing to but distinct from Cunard's celebrity is the way in which her persona has been deployed in literature. Cunard was the model for several literary heroines, perhaps most famously Iris March in Michael Arlen's The Green Hat (1924). Subsequently adapted into the 1928 Oscar-nominated silent film, A Woman of Affairs, starring Greta Garbo, The Green Hat paints Cunard as a fashionable femme fatale and literary dilettante. As a condemnation of Cunard's seriousness, one of the more damning indictments comes when the narrator describes March as violently defending Imagist poems, though it turns out "she hadn't read any, and wasn't at all sure what they were" (24). Another former lover, Aldous Huxley, dramatized Cunard in the novel Antic Hay (1923), where she is the model for Myra Viveash, a witty, intelligent and self-assured woman who attracts and consumes men and then rejects them, a scenario that recurs in Huxley's subsequent characterizations of Cunard in Those Barren Leaves (1925) and Point Counter Point (1928). A pervasive theme in these portraits is the vivacious party-girl who pursues her causes with great vigour but doesn't understand them very well. Descriptions of Cunard by other associates and friends-including Robert McAlmon, Kay Boyle and Solita Solano-evoke a passionate, intelligent woman, similar to William Carlos Williams' description: "if there was anything that was not in that courteous, cultured, and fearless mind, I have yet to discover it" (56). Mina Loy's poem "Nancy Cunard" intriguingly focuses on Cunard's body, betraying, perhaps, Loy's exposure to the plethora of photographs and paintings that emphasized Cunard's physical presence: "The vermillion wall/ receding as a sin/ beyond your moonstone whiteness" (6-8). Visual depictions of Cunard's body circulated through paintings, sketches and sculptures by Wyndham Lewis, John Banting, Eugene MacCown, Oskar Kokoschka, and Constantin Brancusi among many others. Perhaps most famous of these were the photographs taken by Man Ray in 1926 which emphasize Cunard's signature bracelets, blackrimmed eyes, and stark silhouette in a way that suggests glamour, aggression, and an ambiguous, though certainly exoticized, relationship with African culture. Many of Cunard's contemporaries-as well as subsequent critics and biographers-first encountered Cunard through the Man Ray photographs, and their impact is such that they condition a particular type of reception "exalting," as Leo Braudy suggests, "a momentary state of physical being" (554).

In addition to these representations in art and fiction, Cunard and Cunard-based figures also appear in several of her contemporaries' accounts. Critic Hugh Ford, who spent a significant amount of time with Cunard in the later part of her life reported that while Cunard came to "loathe and [...] fear" the "maliciousness" of the press, she was particularly put out by "remarks she found about herself in chronicles of the twenties and thirties, nearly all of which 
were written by friends" (viii). While these accounts might be merely annoying for someone with an established literary reputation, for Cunard they represented another series of moving, acting images which exceeded and defined her in the public imagination. These types of accounts include a posthumous passage about Cunard's later-life descent into alcoholism and mental illness by friend and screenwriter Anthony Thorne, whose scripted reminiscence of Cunard very much evokes the conventions of film. This lends his account, "A Slice of Nancy," a particular vividness which has been transcribed, including its filmic qualities, into subsequent biographies of Cunard (notably Gordon's). Thorne, who writes that Cunard returned to England from a late trip to Spain with "a cracked hip and a damaged mind," begins with a scene narrated to him by his wife:

The bell rang after midnight and there was Nancy having a violent argument with a taximan. She had lost her money somewhere and her baggage too suitcases full of valuable ivories scattered over the stations of London. It was a weekend, and my wife had just enough money to pay the fare, but no tip. "No tip anyway," shouted Nancy. "He tried to have an affair with me, he even pushed my head under the wheel." She came in with a paper bag full of ham sandwiches which, refusing the offer of other food, she then ate, hurling the crusts into the empty fireplace. At one point she picked up a Fornasetti ashtray, demanding: "Is this supposed to be pretty?" and was about to hurl it after the crusts when my wife stopped her. She had to get Nancy to bed before they were both out of their minds. "No sheets!" protested Nancy as clean ones were produced. "If you sleep in this bed," my wife said firmly, "you will have sheets." Nancy gave way. Restless in another bedroom my wife contemplated the possibility of the house being burnt down over her head. (It could have happened, for not long afterwards Nancy showed the familiar and expected signs of incendiarism, and on one occasion, in another flat, set fire to her clothes, declaring: "I shan't need these any more!") In the morning Nancy telephoned to ask who else would give her a room, intending to make a round of visits in London - and it is interesting to remember the distinguished friends who found reasons why they could not see her.

From here, Thorne segues into a second scene, describing his own interaction with Cunard after she had been committed at St. Clements Hospital in 1960, from which, after ten days, and officially certified, she was transferred to Holloway Sanatorium in Surrey:

When I came back to England she was already in an asylum, "certified insane." It was a dismal place in the East End, doors firmly kept open (why do they have doors anyway?) and a shuffling procession of people who giggled momentarily, staring at one another. There was Nancy, lying on the coverlet of her bed, fully dressed and with the usual bandeau across her forehead. Instinctively you looked for the little altar of ivories and beads spread on a bright cloth, and then was thankful that it was missing: for this room, this cubicle in this place, she must never make her own. There was a Negro with her, a young man just arrived from Ghana. Hearing somehow that Nancy was in this hospital he had come to see her for the first time, bringing flowers and a photograph of himself. It was gradually beginning to dawn on him what kind of hospital this was, and I admired the coolness and good sense with which he came to accept the situation. But alas, when she demanded some matches he gave them to her and she tucked them away one by one into the hem of her skirt, like a refugee hiding jewels, and with an expression of cunning that I had never seen on her face before. (306) 
Here, the narration suggests the filming cues: a shot of the inside of the asylum and the "shuffling," "giggling," patients, a cut to Cunard lying on the bed, a pan-shot mirroring the narrator's looking for "the alter of ivories," a return to the bedside and the somber young man from Ghana and the exchange that leads to a close-up of Cunard's expression of "cunning." On one level the description provides insight into the final phase of Cunard's life. On another, it seems gratuitous, the kind of biography that John Updike characterizes as seeking "to expose the writer in his or her fallible, or downright woeful, humanity" (12). The image of Cunard wandering the streets of Paris, railing against the fascists, in the days before her death is one that has attached itself to her reputation, providing the irresistible arc of Greek tragedy to the story of her life, the tale of greatness brought low by some form of hubris or over-zealous pursuit. In Cunard's case, the performance as "filmed" and delivered by Thorne has tended to confirm for her critics something unhinged in her all along, as though her activism presaged the fall and, dramatically speaking, was the only possible end for someone who had pressed her causes too ardently and for the wrong reasons.

Despite the vividness of the characterizations deployed in tabloid and literary accounts, some of the most divergent personas emerge in the academic realm, where critics have tended to either celebrate the progressiveness of her racial causes or deride the underlying naïve white liberalism that is seen to have motivated them. These differences of critical opinion have led to two distinctly different cultural personas: Cunard as race-reformer, a pioneer of transatlantic black studies (see Marcus and Joannou) or Cunard as primitivist racist who essentializes and performs a misguided and degrading caricature of blackness (see Lemke and Archer-Straw). In arguing for the persona of civil-rights activist, critics have pointed to the monumental four-year project of editing Negro Anthology (1934), to Cunard's fundraising and activism, and to her journalism for papers including The Associated Negro Press. In unpacking the romantic misapprehension that may have informed these activities, critics tend to rely on the Man-Ray and Key-Seymer photographs, the latter of which includes solarized prints of Cunard with a black face, lynched by a string of pearls.

My interest in writing a play about Cunard was not to reconcile the contradictions in her various representations or even within her own life and work. Rather, there is something intriguing about the surplus of images and associations attached to Cunard and something at once compelling and flawed about her activism. Perhaps the most interesting element of working on Cunard, however, is the way in which there is seldom a meeting-and here Gordon's biography is an exception-between the representations of identity that circulate around Cunard and her own autobiographical writing, notably in These Were the Hours: Memories of My Hours Press, Réanville and Paris, 1928-1931, as well as in self-referential commentary in Grand Man: Memories of Norman Douglas and GM: Memories of George Moore. The persona that Cunard performs in these works is serious, diligent, hard-working, professional, and balanced. She is careful, articulate, and discrete. This passage, which describes her work at the Hours Press in her memoir, These Were the Hours, is typical both of the tone and content of her autobiographical writing:

The smell of printer's ink pleased me greatly, as did the beautiful freshness of the glistening pigment. There is no other black or red like it. After a rinse in petrol and a good scrub with soap and hot water, my fingers again became perfectly presentable; the right thumb, however, began to acquire a slight ingrain of grey, due to the leaden composition. I soon learned that greasy black hands do not matter when one is at the proofing stage, but an immaculate touch is most important in handling the fair sheet when one has reached the pulling stage. This is part of the craft; to achieve impeccably clean things with fingers grease-laden - else there will be a distressing "printer's thumb" in ink on the finished article. (9) 
Here, Cunard's persona is crafted out of the work she has undertaken, an illustration of mastery anchored in the accumulation of knowledgeable detail. Similarly, in her writing about Crowder, it is the work they undertook together that is stressed, with very little of the glamour and excessiveness with which she is normally connected. In sum, in writing herself, Cunard deliberately chooses a form of professional, working self-presentation in deliberate contrast with the images in media and literature which so often focus on the sensational. This does not exculpate Cunard from the critique of romanticism or more endemic forms of prejudice, but my work to date has shown that Cunard's autobiographical articulations do need to be addressed as they substantially modify the debate and amplify our ability to understand ideological diversity within the attitudes and behaviours of the 1930's.

In an early draft of my play, These Were the Hours, it was Cunard's working persona that I aimed to bring forward, crafting a performance script out of Cunard's autobiographical writing. This was a one-person show, set at Cunard's home in La Chapelle Réanville in 1945, in the moment where she returned home after years abroad to find her home and what was left of the press destroyed, first by German soldiers and French reservists, and then by her neighbours who were let in by the mayor who opposed Cunard's politics and activities. In the end, however, this draft proved too claustrophobic, providing only Cunard's perspective and eliminating most of the drama that was to be derived from her multiple collisions with the outside. In later drafts, I incorporated this autobiographical "sub-script" into a more realized version with multiple characters. Nonetheless, Cunard's autobiographical account-and her working personaremain the stable constant and the most steady source of quotation throughout the play. This has been brought into dialogue with other characters, images, and events from the time Cunard began the press in 1928 to her post-Second World War return. In what follows, I have included an excerpt of the early draft in order to provide a sense of Cunard's working persona as she expressed it in her autobiographical writing. I have also included an excerpt from a later version which dramatizes Cunard's account, drawing her autobiographical voice into dialogue with other characters. In so doing, I hope to reveal the voice and the persona that Cunard herself perceived as central to her own sense of being, the one that is so often elided in accounts of her life and work. At the same time, the later draft shows how this voice can be drawn into some kind of dialogue or confrontation with other personas or circulating versions of Cunard. In presenting a portrait of the working process of research-creation, I am interested in providing an account of both process and labour to make visible some of the structures of production, and perhaps, like Cunard, to provide some insight into the work itself.

\section{WORKING DRAFT OF THESE WERE THE HOURS:}

\section{Cunard's Race-Activism, Editorship, and Relationship with Henry Crowder}

In the early draft of this scene, when the production was still conceptualized as a onewoman show, Cunard's monologue is woven out of autobiographical sources detailing her relationship with Henry Crowder. In this sense, it gives a strong sense of the voice and persona that Cunard creates within her own writing.

\section{NANCY}

Henry, always a thoughtful, serious-minded man (although on occasion in a rhapsodically rollicking mood) was sick to death of night hours, of all the drinks sent to him at his piano, of the fatigue attendant on the adulation of Montmartreii and those interminable "crap-games" at dawn he and the other coloured musicians would be playing in the "Flea-Pit", too weary to go home and sleep. I got him away from all of that and we hired a piano for Réanville. Now he and Monsieur Lévy and I pulled the press together on printing-day. iii

The photograph fades and NANCY drifts back to the press. 
We had become very good ... friends ... and I was intensely interested - amazed too - at what I learned from him about the life of the American Negro. ... Henry himself became a great turningpoint in my own. Of course my feeling for things African had begun years go with sculpture, and something of these anonymous old statues had now, it seemed, materialized in the personality of a man partly of that race. iv Sometimes I would ask Henry to be more African and he would say “I'm not African, I'm American!” People always accuse me of confusing the person with the cause. But those two things are rather confused anyway, don't you think?v

Eventually rumours reached England and my mother's vicious circle. "Well, Maud, what is it now?" one of her rivalsvi asked at a party, "Drink, drugs, or niggers?"vii When a reporter asked her if the rumours were true my mother responded: "Do you mean to say my daughter actually knows a negro?"viii Even when I asked my good friend George Moore if he had any friends of colour he said: "No, I think none, but the subject has never come my way. You see, I've never known anyone of color, not even an Indian. I have met neither a brown man, nor yet a black man. I do not believe I could get on well with a black man, my dear. I think the best I could manage would perhaps be a yellow man."ix That's how it was in England. My mother hired a private detective to prowl around our rooms when Henry and I were in Paris, and tried to keep Henry from entering England at all. I suppose that's what broke things - that and the pamphlet.

Was it wise, in the end, to enumerate all of her flaws, publicly, all of her snobbisms, race and class? To publish and distribute it to all her friends and foes? But it was for a cause! To break down those barriers in England as well as America!

Well, I had absorbed with so much interest and indignation Henry's account of the horrible strife between black and white in the United States, but it was not this alone which led me to make my Negro Anthology, $\mathrm{x}$ a thousand pages of writing by negro people and the negro experience around the world! No one had ever seen anything like it. Poetry, fiction and nonfiction, mostly by negro writers and sympathizers. Langston Hughes. ${ }^{x i}$ Zora Neale Hurston. ${ }^{x i i}$ So mother and her friends, so everyone could see the real conditions of darker people. So they could understand ... In the end, Henry made me, xiii though I could never have anticipated the outrage, the violence. A black man and a white woman! It was bad enough in London, but in Harlem. The letters I received!

\section{FINALIZED VERSION OF THESE WERE THE HOURS}

\section{Cunard in Harlem, Race-Activism, Editorship of Negro Anthology and Relationship with Henry Crowder}

In working on the play script-and in receiving honest and helpful commentary from both theatre professionals and academics - it became clear that staging Cunard's selfpresentation and self-constructed persona was not nearly enough to bring about a complete, complex, and dramatically satisfying portrait. As a result, the play was turned into a 18character ensemble production which contrasts Cunard's autobiographical persona with other voices and perspectives. The monologue above, which addresses Cunard's relationship with Crowder, her fall-out with her mother over Black Man and White Ladyship (1931), the beginning of the editorship of Negro Anthology, and Cunard's experience in Harlem was divided, in the final version, into three discrete scenes. xiv The scene below is the depiction of Cunard's experience in Harlem, which contrasts her own writing and journalism with other journalistic transcripts, Cunard's writing on the infamous Scottsboro case, and dialogue grounded in the auto/biographical accounts of Cunard and Crowder. 
Scene 8. A hotel in Harlem, April 1932. The front of the hotel is projected onto an of S.R. On what amounts to the fourth floor, there is a platform which represents NANCY's hotel room. NANCY hurries past at stage level, and is accosted by the reporters who are standing in the front row the audience.

\section{REPORTER 1}

Nancy! Nancy! What's an heiress doing in Harlem anyway?

\section{REPORTER 2}

Miss Cunard, what about these reports of negro men coming and going from your hotel at all hours?

\section{REPORTER 3}

Hey - Miss Cunard, what's your mother think about you seeing a negro movie star? Is that why you're both staying at this hotel?

NANCY looks as though she is going to flee into the hotel, but then turns to make a statement.

\section{NANCY}

I have one thing to say, and that is to deny the printed allegation about my involvement with Paul Robeson. ${ }^{\mathrm{xv}}$ He is a very fine actor. I admire his work. Beyond that, I have only met him once at a club in Paris, le Boeuf sur le Toit, in 1926. That is all.

\section{REPORTER 1}

Nancy! Are you saying your affair with Robeson started back in Paris?

\section{REPORTER 3}

What other bohemian activities can you tell us about?

\section{NANCY}

And now after your interest in my private affairs (I hope I have sufficiently satisfied this) I want something in return. [...] Why are you Americans so uneasy of the Negro race? This question is the epitome of the whole colour question as it strikes a plain English person such as myself. Who'll write me the best answer to this? I'll print it in my book on Colour.xvi

\section{REPORTER 1}

Nancy - Is the book a pretext for coming to America?

\section{REPORTER 2}

Nancy! Hey, Nancy.

\section{REPORTER 3}

Are you planning to star in a film with Mr. Robeson? 
NANCY exits stage into the hotel and reemerges on the fourth floor platform. Books and papers are scattered on the desk and the beds. Langston Hughes'xvii poem "I, too" is projected on the wall of the hotel room as she enters. As the neon hotel sign flashes, so too do we see flashes from the pages of Negro Anthology photographs, text, music scores. The red light and the images play on the room and on NANCY.

NANCY removes her coat and scarf and sits down at the desk.

\section{NANCY}

(Taking a breath) Right. Back to work. Scottsboro.

NANCY begins to write and then looks up as she narrates her article. During her description, we see photographs and film footage from the Scottsboro case on the wall of the hotel.

On March 25, 1931, black and white hoboes were "riding the rails," hidden up and down the length of a freight train going from Chattanooga to Memphis, Tennessee. No money, no fares, setting out to look for work. Travelling in this manner is a frequent occurrence in America. But such is the race hatred that white tramps even will object to the presence of Negro hoboes in the same wagon. Not for nothing has the white ruling class for decades been teaching the "poor white" that he can always look down on the Negro worker, no matter how wretched his own economic condition may be. So the white boys started a row and tried to throw the "niggers" off. The Negroes resisted them, and the whites did not get the best of it. All but one jumped off and telephoned the station-master at Stephenson to arrest the "niggers" who'd dared to fight with them.

The train had already gone through this station, so was stopped at Paint Rock. Here sheriffs and excited citizens took 9 Negro boys and 3 white boys out of separate parts of the train. At first all were charged with vagrancy and told to get out of that county as quick as possible. And then suddenly, while all were being searched, two of the white boys were discovered to be girls in men's overalls. So the sheriff got an idea; it wasn't possible for Negroes and white girls to be on the same train, in the same car maybe, without the question of rape coming in. The boys protested they had not even seen any girls; some of them had seen a fight, that was all. But some of the crowd were for an immediate lynching; authorities assured them the "niggers" would be properly dealt with and should not escape "justice." All were promptly locked up, the Negroes to be brutally beaten, the girls to be put through the third degree and forced into saying they had been repeatedly raped by the boys. Both girls were known to be prostitutes; Victoria Price had a prison record and impressed on Ruby Bates the utter necessity, now, of falling in with the authorities' views so that they might themselves escape the law's punishment.

The phone rings. NANCY answers it abstractedly. 


\section{MALE AMERICAN (VOICE)}

I don't know what they call your kind in England but here in America they call them plain nigger fuckers or prostitutes of the lowest kind ... ${ }^{\text {viii }}$

NANCY is startled and hangs up phone. She walks over to the bar and pours herself a drink. She takes a drink, steadies herself, then returns to her narration with projections.

\section{NANCY}

The trial date was first of all fixed for April 1, but postponed till April 6, a fair-day in Scottsboro, one which would assure the largest crowd possible and enable the mob to witness the condemnation of what the local papers called "the Negro fiends." Scottsboro is described as a sleepy little town of some 10,000 inhabitants in the northern part of Alabama, but on trial day the presence of the military who had been called in to make a show of quelling the lynch spirit made it look like an armed camp. The authorities had deemed it necessary to send 118 soldiers to bring the nine boys in to the town from Gadsden jail, where they had been held since arrest.

Armed soldiers were on guard inside and outside the court house, to which only persons holding special permits were allowed entry after having been searched. Already by 8 A.M. thousands had gathered from all over the neighbourhood, and by 10 o'clock the crowd was estimated at 10,000. The lynch spirit had been whipped up to such a point by the authorities that statements were going around saying that the "horrible black brutes had chewed off one of the girl's breasts." The doctor's evidence - and this is the most important part - on his examination of the girls immediately after they were taken from the train, showing they were unscathed, and which was public knowledge, meant nothing to the people of Scottsboro. The local newspapers tried to whitewash the presence of the agitated mob by saying the crowd was "curious, not furious," and maintained it had gathered out of mere curiosity.

The trial began on the $6^{\text {th }}$ and was all over on the $8^{\text {th }}$ of April, 1931 - three days to convict and sentence to death 9 Negro boys all under 20 years old, two of them 13 and 14 respectively, one boy with a sexually transmitted infection so severe he could not possibly have participated in any rape. There were no workers on this jury, not white nor black. It was composed of local business men and neighbouring well-to-do farmers. Just before the proceedings began, Wembley, the legal advisor to the Scottsboro Electric Company, which controls the town, had walked through the mob and told them that "everything would be alright in a few days," and that his company had enough power to "burn up the niggers." In court, the boys had a lawyer who had not, on his own statement, studied nor prepared the case, and told them to plead guilty. The boys were tried without having been allowed to communicate with parents, relatives, or friends, yet maintained their innocence.

HENRY hurries by the reporters his way into the hotel.

\section{REPORTER 1}

Hey, Henry! Give us a quote.

\section{REPORTER 2}

Mr. Crowder, what's it like sharing Miss Cunard's attention?

HENRY enters the hotel room with a handful of letters. He throws off his hat and puts the mail on the desk 


\section{HENRY}

Those reporters -

\section{NANCY}

I know. They won't give up. It's sordid. Why won't they get behind our cause instead? They could be shedding light on the cultural accomplishments of a people. What could be a better use of journalism than that?

\section{HENRY}

(Taking off his coat) That's the fabric of this place, Nancy. There's a lot of hate.

\section{NANCY}

What's come in the mail then?

HENRY picks up the letters and sits down on the bed, sorting through the mail.

\section{HENRY}

Oh the usual, more threats. Damn if those people aren't crazy enough to follow through.

\section{NANCY}

You can't listen to them.

\section{HENRY}

Can't afford not listen. This press storm's gone berserk. Someone's going to do something.

\section{NANCY}

We can't quit, Henry. We already have over five hundred pages collected. And the additions on Harlem will add a whole new dimension. I've been writing notes on the vitality of the children here ... What else?

\section{HENRY}

Letter from a Scottsboro mother, thanking you for the money.

HENRY hands NANCY the letter. She skims it.

\section{NANCY}

I'm working on that article now -

HENRY opens another envelope and looks at the enclosed photographs.

\section{HENRY}

Lord knows those boys need all the help they can get. Here's a contribution from Lawrence Gellertxix called "Negro Songs of Protest"

I've been waiting for that.

\section{NANCY}




\section{HENRY}

And Micheletxx has sent a draft of "African Empires and Civilisations"

\section{NANCY}

Wonderful.

\section{HENRY}

Huh. Prints from Barbara Ker-Seymer.xi (Checks the postage) Guess they've been following us around in the mail.

\section{NANCY}

Oh! How do they look?

\section{HENRY}

(Sorting through the photographs) Some are real good. This one with you in the veil.

The solarized photograph of Cunard appears on the screen.

\section{HENRY}

But this one where the negative's been used to make your skin look black - Nancy, what were you thinking?

\section{NANCY}

(Taking the photograph and admiring it) It was Barbara's idea. It's a new technique called solarization. Really quite remarkable.

\section{HENRY}

But it looks like your skin's black and those pearls around your throat are choking you. Like you're being lynched. Don't you have any idea what this looks like to a black man?

\section{NANCY}

Henry, you of all people should know. It's an identification. An expression of solidarity.

Photo fades.

\section{HENRY}

It's two little girls playing with film.

\section{NANCY}

Playing!

\section{HENRY}

Bright Young Things. ${ }^{\text {xxii }}$ Is that what they called you? The Corrupt Coterie?xxii You think because these photographs make your skin look black that you know? What kind of danger you've put me in here?

\section{NANCY}

(Taking a breath) Henry, I realize the pressures are extreme - 


\section{HENRY}

You play at lynching, but this is real life for me, Nancy. It's not a cause or a .... a romantic infatuation.

NANCY

Is that what you think it is for me? After all of the work, the hours ...

\section{REPORTER 1}

(Yelling up) Nancy. Hey - Nancy - Just yell something down. Is it true or ain't it?

NANCY calms herself, steps over to the window and looks down.

\section{NANCY}

They think I slept with Paul Robeson - they've printed it.

HENRY is silent.

\section{NANCY}

Oh, come on. The accusation is ludicrous.

\section{HENRY}

I know you are infinitely capable of living three or four lives at once.

\section{NANCY}

I belong to you, Henry. You've made me. All of my ambitions.

\section{HENRY}

If you belong to me you also belong to a whole hell of a lot of others. The danger I'm in here -

The phone rings. HENRY looks at it suspiciously, NANCY with trepidation. HENRY's look challenges NANCY to answer it. She does, slowly.

\section{NANCY}

Hello.

\section{MALE AMERICAN (VOICE)}

Mrs. Nancy Cunard take this as a solemn warning, your number is up. You're going for a ride shortly. You are a disgrace to the white race. You can't carry on in this country. We will give you until May $15^{\text {th }}$. Either give up sleeping with a nigger or take the consequences. That is final. P.S. - We will not only take you but we'll take your nigger lover with you. xxiv

NANCY hangs up the phone.

\section{HENRY}

Who was that?

\section{NANCY}

I don't know. Men have been calling. 
HENRY

(Sarcastically) Have they?

HENRY grabs his coat and hat.

NANCY

Henry -

HENRY exits, slamming the door. NANCY stares a moment, then slowly sits at her desk and continues her narration with projections.

\section{NANCY}

In appeal upon appeal those boys were convicted and sentenced to death or life imprisonment, even when Ruby Bates came out and repudiated the rape lie. Victoria Price's testimony was full of gaps and contradictions but that did not matter to the juries. And so they remain imprisoned, most waiting to die, for a lie, for a terrible lie, for a crime the evidence itself says they did not commit. Such is justice for the American negro today. ${ }^{\mathrm{xxv}}$

Blackout except for the flashing neon images from Negro.

\section{CONCLUSION}

The effect, in workshopping this scene, has been to attach the discourse around Cunard to a representation of the site from which it emerged: the thinking, speaking, moving body, the fluctuating human mind, the variegations of human motives and behaviour. What the dramatization of Cunard's personas has added, in my view, is a dynamism to the fixedness of analysis, a mobility and variation which will only increase as the unpredictable element of live audience is introduced. In this sense, the play-and researched biographical drama more gen ${ }^{1}$ erally-at once relies on autobiographical sources and, to a certain extent, challenges the presentations contained with them by exploring the complexly human dimensions and motivations that have led to the creation of the personas that surround Cunard. Now that the play is complete, production will be the next step, to put this coalescence of personas on the public stage through the feeling, speaking body of the actor and to see what larger audiences, many previously unfamiliar with Cunard, will make of her. This, in turn, will at once enrich and complicate the relationship of autobiography to stage and persona, as both actors and audiences bring their own sense of Cunard to the theatre. To the extent that the processes at play in live drama are multiple and complex, they seem uniquely suited to Cunard and the variegated, contradictory impulses and representations that have attached themselves to her image.

\section{END NOTES}

i While Cunard is frequently hailed a both racist and race reformer, it is clear that neither applies neatly or precisely. Cunard's views on equality are too clear cut to really bear 
out claims of racial prejudice. At the same time, her romanticism and her essentializing are problematic for contemporary audiences, in particular. It is likely more productive to study Cunard's comments anthropologically and within their social and historical contexts in order to understand the complex emergence of early civil rights rhetoric of Britain in the 1930's.

ii Right-bank Paris neighbourhood popular with artists and musicians during La Belle Époque and modernist periods.

iii Cunard, Grand Man: Memories of Norman Douglas, 85-6.

iv Adapted from Grand Man 85

v Extrapolated from descriptions in Gordon.

vi Margot Asquith, Lady Oxford (1864-1945).

vii "Black Man and White Ladyship" 181.

viii Qtd. in Gordon, 157.

ix Ibid.

x Hours, 152 .

xi Langston Hughes (1902-1967). American writer.

xii Zola Neale Hurston (1891-1960). American writer.

xiii "Henry made me" letter to a friend on learning of Crowder's death, qtd. in Gordon, 173.

xiv As a "political pamphlet" Black Man and White Ladyship is a particularly interesting example of the ways in which Cunard positions herself in the media, notably in her attempt to differentiate herself from her mother's views on race, which Cunard considers to be primarily a manifestation of class prejudice. In this sense, the pamphlet is highly illustrative of the ways in which Cunard at once rejected her class position yet also used its privilege and associated media spotlight in order to further her causes. The blurring of the personal and the political within the pamphlet is also revelatory of the complications of separating out the "work" of Cunard's activism from the family-life that made her famous.

xv Paul Robeson (1898-1976). American actor and civil rights activist.

xvi Quoted in Anne Chisholm, Nancy Cunard: A Biography, 195.

xvii Langston Hughes (1902-1967). American writer.

xviii Anon. letter to Cunard, qtd. in Winkiel, 512.

xix Lawrence Gellert b. Laslow Grünbaum (1898-1978). Hungarian-American writer and music collector.

xx Raymond Michelet, Cunard's collaborator on Negro: An Anthology.

xxi Barbara Ker-Seymer (1905-1993). British photographer.

xxii Tabloid nickname for a group of bohemian young people in London during the 1920 's, including Barbara Key-Seymer. While peripherally associated with the group, Cunard spent most of the twenties in Paris. 
xxiii Group of aristocratic young people in London during the 1910's, including Cunard, known for their extravagant parties.

xxiv Quoted in Nancy Cunard, "The American Moron and the American of Sense - Letters on the Negro" in Negro: An Anthology, 121.

xxv Adapted from "Scottsboro - and other Scottsboros" ibid, 155-174.

\section{WORKS CITED}

Alberoni, Franceso. "The Powerless 'Elite': Theory and sociological research on the phenomenon of the stars." The Celebrity Culture Reader. Ed. P. David Marshall. New York and London: Routledge, 2006. Print.

Archer-Straw, Petrine. Negrophilia: Avant-Garde Paris and Black Culture in the 1920's. London and New York: Thames and Hudson, 2000. Print.

Arlen, Michael. The Green Hat. London: Collins, 1924. Print.

Braudy, Leo. The Frenzy of Renown. New York: Vintage, 1986. Print.

Brown, Clarence, dir. A Woman of Affairs. 1928. DVD.

Chisholm, Anne. Nancy Cunard: A Biography. New York, NY: Knopf, 1979. Print.

Cunard, Nancy. Black Man and White Ladyship: An Anniversary. Toulon: Privately printed, 1931. Print.

---. GM: Memories of George Moore. London: Rupert Hart-Davis, 1956. Print.

---. Grand Man: Memories of Norman Douglas. London: Secker \& Warburg, 1954. Print.

---, ed. Negro Anthology. London: Wishart, 1934. Print.

---.Outlaws. London : Elkin Mathews, 1921. Print.

---. "Scottsboro - and Other Scottsboros. Negro: An Anthology. Eds. Nancy Cunard and Hugh Ford. London and New York, NY: Continuum, 2002. Print.

---. These Were the Hours: Memories of My Hours Press Réanville and Paris 1928-1931. Carbondale: South Illinois UP, 1969. Print.

Cunard, Nancy and Hugh Ford, eds. Negro: An Anthology. New York and London: Continuum, 2002. Print.

Ford, Hugh. "Foreword." Nancy Cunard; Brave Poet, Indomitable Rebel 1896-1965. Ed. Hugh Ford. Philadelphia, New York, London: Chilton Book Company, 1968. Print.

Geraghty, Christine. "Re-examining Stardom: Questions of Texts, Bodies and Performance." Stardom and Celebrity: A Reader. Eds. Sean Redmond and Su Holmes. Los Angeles, London, New Delhi, Singapore: Sage Publications, 2007. 98-110. Print.

Gordon, Lois. Nancy Cunard: Heiress, Muse, Political Idealist. New York: Columbia UP, 2007. Print.

Hughes, Langston. "I, Too." Negro: An Anthology. Eds. Nancy Cunard and Hugh Ford. London and New York, NY: Continuum, 2002. Print.

Huxley, Aldous. Antic Hay. Hamburg: The Albtross, 1932. Print.

---. Point Counter Point. Leipzig: Tauchnitz, 1929. Print.

---. Those Barren Leaves. New York: George H. Doran, 1925.

Joannou, Maroula. “Nancy Cunard's English Journey.” Feminist Review 78 (2004) 141-163. Print.

Lemke, Sieglinde. Primitivist Modernism. Oxford and New York: Oxford UP, 1998. Print.

Loy, Mina. Lost Lunar Baedeker. New York, NY: Farrar, Straus and Giroux, 1997. Print.

Marcus, Jane. Hearts of Darkness: White Women Write Race. New Brunswick, NJ: Rutgers UP, 2004. Print.

Marshall, P. David and Kim Barbour. "Making Intellectual Room for Persona Studies: A New Consciousness and a Shifted Perspective." Persona Studies 1.1 (2015): 1-12. Web.

Pound, Ezra. The Cantos of Ezra Pound. New York: New Directions, 1995. Print. 
Stanford-Friedman, Susan. "Nancy Cunard." The Gender of Modernism: A Critical Anthology. Ed. Bonnie Kime Scott. Bloomington, IN: Indiana UP, 1990. 63-67. Print.

Thorne, Anthony. "A Share of Nancy." Nancy Cunard; Brave Poet, Indomitable Rebel 1896-1965.

Ed. Hugh Ford. Philadelphia, New York, London: Chilton Book Company, 1968. 293-311. Print.

Updike, John. "On Literary Biography." Due Considerations: Essays and Criticism. New York: Alfred A. Knopf, 2007. Print.

Williams, William Carlos. "Nancy Cunard." Nancy Cunard; Brave Poet, Indomitable Rebel 18961965. Ed. Hugh Ford. Philadelphia, New York, London: Chilton Book Company, 1968. 56-57. Print.

Winkiel, Laura. "Nancy Cunard's Negro and the Transnational Politics of Race." Modernism/Modernity 13.3 (2006): 507-530. Print.

Sasha Colby is Director of Graduate Liberal Studies at Simon Fraser University in Vancouver. She is the author of Stratified Modernism: The Poetics of Excavation from Gautier to Olson as well as numerous plays focused on engaging communities with political and social issues. The author acknowledges support for this article from the Social Sciences and Humanities Research Council of Canada. 